\title{
O futuro da questão indígena
}

\section{MANUELA CARNEIRO DA CUNHA}

Heródoto (História, 82) quem conta que os argivos e os lace-
demônios estando em guerra por causa de um território, travaram-
se duas batalhas. "Em seguida a esses acontecimentos", escreve Heródoto, "os argivos cortaram os cabelos, que até entáo eram obrigados a usar longos, e promulgaram uma lei, corroborada por imprecaçóes, segundo a qual nenhum argivo deixaria crescer os cabelos (...) enquanto eles náo reconquistassem Tirea; os lacedemônios, por seu turno, promulgaram uma lei em sentido contrário, segundo a qual, daí em diante eles, que até entáo náo usavam cabelos longos, passariam a usá-los" .

Há dois modos básicos de se entender a noção de cultura e de identidade. O primeiro, a que poderíamos chamar, por simples conveniência, de platónico, percebe a identidade e a cultura como coisas. A identidade consistiria em, pelo menos como um horizonte almejado, ser idéntica a um modelo, e supóe assim uma essência, enquanto a cultura seria um conjunto de itens, regras, valores, posiçóes etc. previamente dados. Como alternativa a esta perspectiva, pode-se entender a identidade como sendo simplesmente a percepçáo de uma continuidade, de um processo, de um fluxo, em suma, uma memória. A cultura náo seria, nessa visáo, um conjunto de traços dados e sim a possibilidade de gerá-los em sistemas

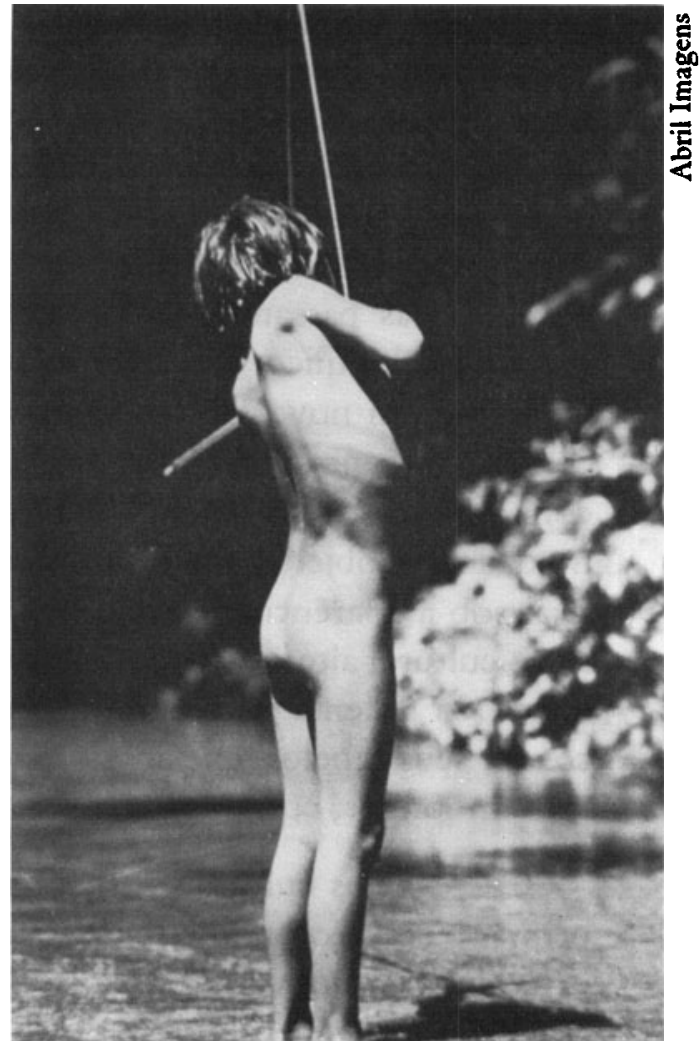

Indio ranomami 
perpetuamente cambiantes. Por comodidade, poderíamos chamar esta postura de heracliteana.

Em vários trabalhos anteriores, explorei os aspectos ligados a esta posiçăo heracliteana, com respeito à etnicidade, que repousa precisamente sobre a noção de identidade e sobre o conceito-chave da antropologia, a saber, a cultura. Apontei que a cultura, ao substituir a noção de raça, herdou no entanto sua reificaçáo. E mostrei, usando a analogia do totemismo, que se pode pensar as culturas, em sociedades multiétnicas, de forma não essencialista e sim estrutural.

Talvez valha a pena explicitar meu argumento: do mesmo modo que o totemismo usa categorias naturais para expressar distinçóes sociais, a etnicidade se vale de objetos culturais para produzir distinçóes dentro das sociedades em que vigora. A etnicidade é portanto uma linguagem que usa signos culturais para falar de segmentos sociais.

As espécies naturais existem em si, são dadas no mundo. Têm uma coerência interna, uma fisiologia que anima e concatena suas partes. Mas não é na sua inteireza que elas interessam ao totemismo. São suas diferenças culturalmente selecionadas que as tornam passíveis de organização em um sistema que passa a comandar um outro significado. O que acontece se passamos das espécies naturais usadas no totemismo para espécies culturais usadas nas sociedades multiétnicas? Do mesmo modo que a fisiologia comanda cada espécie natural, as culturas sáo sistemas cujas partes interdependentes são determinadas pelo todo que as organiza. Se elas passam a ser usadas, por sua vez, como signos em um sistema multiétnico, elas além de serem totalidades, tornam-se também partes de um novo, de um meta-sistema, que passa a organizá-las e a conferir-lhes portanto suas posiçóes e significados. E solidariamente com a mudança do sistema de referência, sem que nada tangível tenha mudado nos objetos, muda também o significado dos itens culturais. $\mathrm{Ou}$ seja, sob a aparência de ser o mesmo, de ser fiel, de ser tradicional, o traço cultural alterou-se. E, reciprocamente, sua alteração em função de um novo sistema não significa mudança étnica: os argivos deixaram crescer seus cabelos, que antes usavam curtos e os lacedemônios, que os usavam longos, cortaram-nos.

Os traços culturais tornam-se assim no mínimo bissêmicos: um primeiro sentido prende-se ao sistema interno, um segundo ao sistema externo. Usar um cocar pariko em um ritual Bororo é uma coisa, usá-lo em uma coletiva de imprensa para reivindicar direitos indígenas na Assembléia Constituinte é outra. Mas o cocar é o mesmo e é essa mesmice que nos induz em erro. Os signos étnicos podem ser elaborados com 
todas as regras da arte tradicional $e$, no entanto, terem um significado externo à cultura em que se originaram: năo por serem falsos mas por serem comandados por um sistema que extrapola a cultura tradicional. São, de certa forma, como trocadilhos, que participam de mais de um código semântico.

Entender estes processos náo é somente importante para a definiçáo de identidade étnica. Na realidade toda a questão indígena (e não só ela) está eivada de semelhantes reificaçóes. No século XVI, os índios eram ou bons selvagens para uso na filosofia moral européia, ou abomináveis antropófagos para uso na colônia. No século XIX, eram, quando extintos, os símbolos nobres do Brasil independente e, quando de carne e osso, os ferozes obstáculos à penetraçáo que convinha precisamente extinguir. Hoje, eles sáo seja os puros paladinos da natureza seja os inimigos internos, instrumentos da cobiça internacional sobre a Amazônia.

Há vários anos, um personagem de nossa vida pública declarou que não era ministro: apenas estava ministro. Eu diria o mesmo dos índios: não são nada disso, apenas estão. Ou seja, qualquer essencialismo É enganoso. A posiçăo das populaçóes indígenas dependerá de suas próprias escolhas, de políticas gerais do Brasil e até da comunidade internacional. Para ser mais específica, entrarei agora em algum detalhe nas características atuais da questáo indígena.

\section{População}

A primeira observaçáo é que, desde os anos 80 , a previsáo do desaparecimento dos povos indígenas cedeu lugar à constataçáo de uma retomada demográfica geral. Ou seja, os índios estáo no Brasil para ficar.

Sabe-se que o primeiro contato de populaçóes indígenas com outras populaçốes ocasiona imensa mortandade, por ser a barreira imunológica desfavorável aos índios (ao contrário do que ocorreu na África, em que a barreira favorecia os africanos em detrimento dos europeus). Essa mortandade, no entanto, contrariamente ao que se quer crer, não tem causas unicamente naturais: entre outras coisas, ela pode ser evitada com vacinações, atendimento médico e assistência geral. Estudos de caso recentes mostraram que, nessas epidemias, os índios morrem sobretudo de fome e até de sede: como toda a populaçáo é acometida pela doença ao mesmo tempo, não há quem socorra e alimente os doentes. Foi o que aconteceu entre 1562 e 1564 quando ficaram dizimadas as aldeias jesuítas da Bahia, onde se haviam reunido milhares de índios, o que facilitou 
o contágio. Os sobreviventes, movidos pela fome, vendiam-se a si mesmos em escravidáo. Hoje a mortandade do primeiro contato, como a que ocorreu entre os Yanomami durante a construção da Perimetral Norte e que perdura com a malária trazida pelos garimpeiros (e que vitimou cerca de $15 \%$ da populaçáo Yanomami entre 1988 e 1990), é algo inadmissível e grave responsabilidade do Estado.

Após o primeiro contato, os grupos que conseguem sobreviver iniciam uma recuperaçáo demográfica: assim foi com a América como um todo, que perdera grande parte de sua população aborígene entre 1492 e 1650, provavelmente uma das maiores catástrofes demográficas da humanidade. Cada avanço da fronteira econômica no país dá origem a um ciclo semelhante. Muitos grupos indígenas foram contactados no início dos anos 70, durante o período do chamado milagre brasileiro, e estão agora iniciando esse processo de recuperação demográfica.

Outro fator de crescimento populacional, embora de menor impacto demográfico, é que muitos grupos, em áreas de colonização antiga, após terem ocultado sua condiçăo discriminada de indígenas durante décadas, reivindicam novamente sua identidade étnica. No século XIX, sobretudo no nordeste, com o falso pretexto da inexistência ou de uma assimilação geral dos índios, as terras dos aldeamentos foram liquidadas e por sinal duramente disputadas entre os poderes locais. Ressurgem agora etnias, sobretudo no leste e no nordeste, que reclamam terras - em geral diminutas, mas por encontrarem-se em áreas densamente povoadas, enfrentam oposiçáo violenta. Os embates legais travam-se geralmente em torno da identidade indígena e aqui o modelo que eu chamei platónico da identidade é amplamente invocado, tanto por parte dos fazendeiros quanto por parte dos próprios índios, forçados a corresponderem aos estereótipos que se tem deles.

Garantia de terras, apoio sanitário, apoio legal têm, portanto, profundo impacto na retomada demográfica dos índios que apenas se inicia. Nos EUA, a população indígena em 1890 era da ordem da população indígena brasileira nos nossos dias, ou seja, na casa dos duzentos e poucos mil. Cem anos mais tarde, essa população havia quadruplicado: no censo de 1990, registravam-se 1,9 milhōes de nativos americanos. É possível que ascenso semelhante se verifique no Brasil, cuja população indígena já aumentou nestes últimos dez anos e situa-se hoje, provavelmente, em torno de $\mathbf{2 5 0 . 0 0 0}$. Mas nunca se voltará à situaçáo de 1500 , quando a densidade demográfica da várzea amazônica era comparável à da península ibérica: 14,6 habitantes por $\mathrm{km}^{2}$ na primeira (de acordo com Denevan, 1976:230), contra 17 habitantes por $\mathrm{km}^{2} \mathrm{em}$ Espanha e Portugal (Braudel, 1972:42). 


\section{Terras}

O grande contingente populacional indígena localiza-se, náo por acaso, na Amazônia. Não por acaso, dizem também os que defendem teorias conspiratórias, como se os índios fossem a ponta de lança de interesses escusos internacionais. Chegou-se a dizer que se traziam índios para onde houvesse riquezas minerais. Os índios são mais numerosos na Amazônia pela simples razão de que grande parte da regiáo ficou à margem, nos séculos passados, dos surtos econômicos. $O$ que se prova até pelas exceçóes: onde houve borracha, por exemplo no Acre, as populaçóes e as terras indígenas foram duramente atingidas e a maior parte dos sobreviventes dos grupos pano do Brasil hoje estáo em território peruano. Quanto aos Yanomami, habitam terras altas que até recentemente não interessavam a ninguém. As populaçóes indígenas encontram-se hoje onde a predaçáo e a espoliaçáo permitiu que ficassem.

Os grupos da várzea amazônica foram dizimados a partir do século XVII pelas tropas que saíam em busca de escravos. Incentivou-se a guerra entre grupos indígenas para obtê-los e procedeu-se a maciços descimentos de índios destinados a alimentar Belém em máo-de-obra. No século XVIII, como escrevia em 1757 o jesuíta João Daniel, encontravam-se nas missóes do baixo Amazonas índios de "trinta a quarenta naçōes diversas". Alguns grupos apenas foram mantidos nos seus lugares de origem para que atestassem e defendessem os limites da colonizaçáo portuguesa: foram eles os responsáveis pelas fronteiras atuais da Amazônia em suas regióes. É o caso dos Macuxi e Wapixana, na Roraima atual, chamados no século XVIII de muralbas do sertão. O Barão de Rio Branco e Joaquim Nabuco fundamentaram na presença destes povos e nas suas relaçóes com os portugueses a reivindicação brasileira na disputa de limites com a entáo Guiana inglesa, no início deste século. $E$ há quem venha agora dizer que os Macuxi se instalaram apenas recentemente na área Raposa-Serra do Sol! Do ponto de vista da justiça histórica, é chocante hoje se contestar a conveniência de grupos indígenas povoarem as fronteiras amazônicas que eles ajudaram a consolidar.

Outra objeçáo que freqüentemente se levanta, paradoxal em um país ocupado por latifúndios numa proporção que beira os $\mathbf{5 0 \%}$ $(48,5 \%)$, é o tamanho das terras indígenas na Amazônia. Já vimos as razóes pelas quais elas se concentram na regiáo, longe das áreas de colonização antiga. Mas grandes áreas na Amazônia não sáo o privilégio de alguns grupos indígenas. A Manasa Madeireira Nacional tinha, em levantamento do Incra de 1986, nada menos do que 4 milhóes e 140 mil hectares no Amazonas: área maior que a Bélgica, a Holanda ou as duas 
Alemanhas reunidas. Em outras regiōes do Brasil, a mesma Manasa tinha mais meio milháo de hectares. A Jari Florestal Agropecuária Ltda. tem quase três milhóes de hectares no Pará. E assim vai. E neste caso, contrariamente às terras indígenas que pertencem à Uniáo, trata-se de terras particulares.

Em matéria de territórios indígenas, o Brasil está longe da liderança. No Canadá (segundo a Folba de S.Paulo, 5 set. 1993, p.3-4),

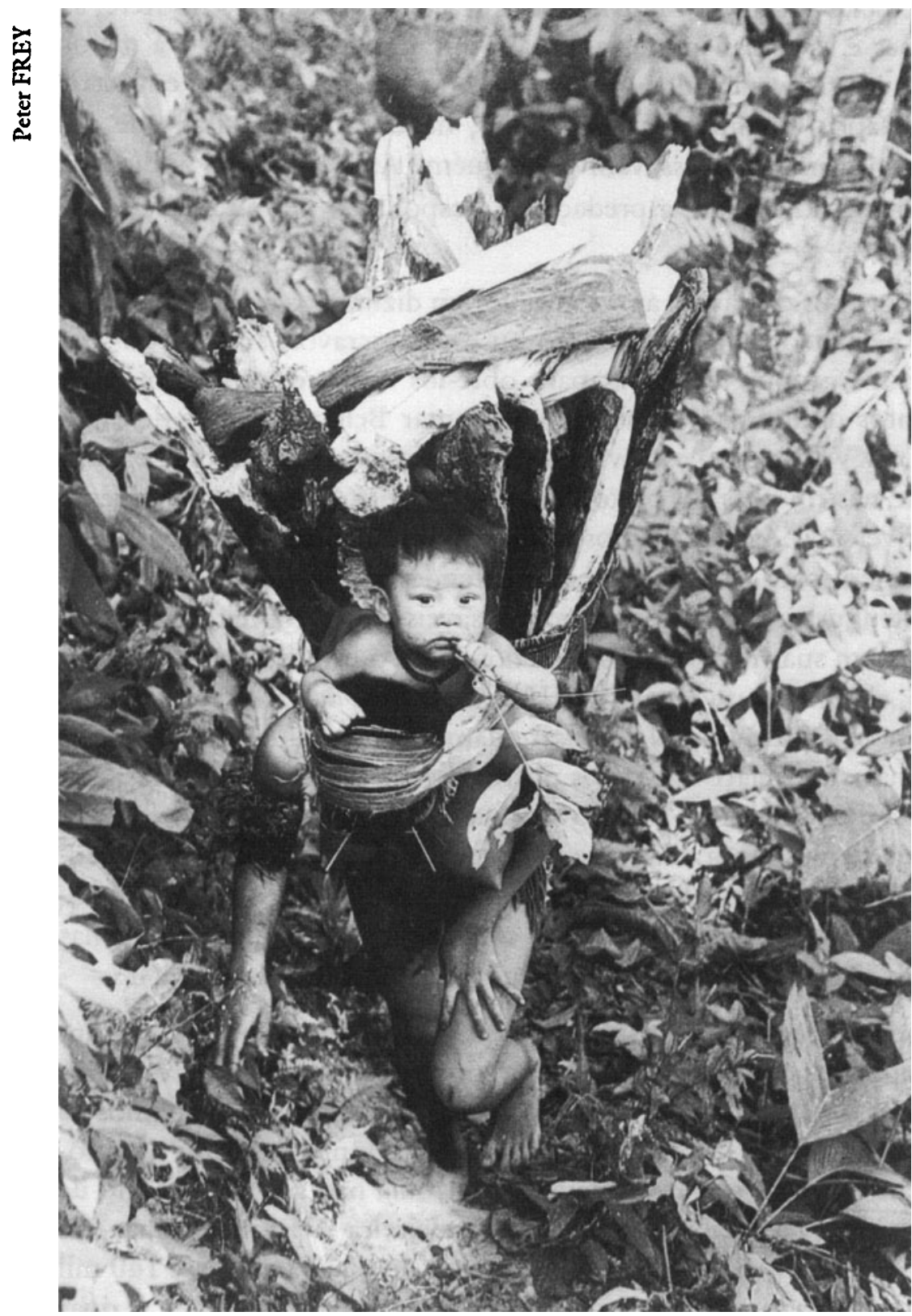

$O$ transporte de lenba e trabalho das mulheres entre os ranomami 
criou-se em dezembro de 1991 um território semiautônomo esquimó (ou Inuit) de cerca de 2 milhóes de $\mathrm{km}^{2}$, (cerca de $20 \%$ do território total do Canadá, e em área contínua), equivalente aos estados de Amazonas, Amapá, Acre e Roraima juntos, com 17.500 habitantes. Em 1/6 do território, os Inuit têm controle absoluto das riquezas naturais e autogoverno. Nos outros $5 / 6$, recebem $5 \%$ sobre a exploração de riquezas naturais. Trata-se de território contínuo que sozinho totaliza mais do dobro de todas as áreas indígenas brasileiras.

No Brasil, com efeito, contam-se atualmente 519 áreas indígenas esparsas que, juntas, totalizam $10,52 \%$ do território nacional, com $895.577,85 \mathrm{~km}^{2}$. Apesar da Constituição (no art. 67 das disposiçóes transitórias) prever a data de 5 de outubro de 1993 para a conclusáo das demarcaçóes dessas áreas, atualmente cerca de metade (256) estáo demarcadas fisicamente e homologadas (Cedi, 1993). As demais 263 áreas estão em diferentes estágios de reconhecimento, desde as 106 totalmente sem providências até às 27 demarcadas fisicamente, mas ainda não homologadas. Acrescente-se o dado muito relevante de que cerca de $85 \%$ das áreas indígenas sofrem algum tipo de invasão.

\section{Direitos}

O princípio dos direitos indígenas às suas terras, embora sistematicamente desrespeitado, está na lei desde pelo menos a Carta Régia de 30 de julho 1609 . O Alvará de $1^{\circ}$ de abril de 1680 afirma que os índios são "primários e naturais senhores" de suas terras, e que nenhum outro título, nem sequer a concessão de sesmarias, poderá valer nas terras indígenas. É verdade que as terras interessavam, na Colônia, muito menos que o trabalho indígena. Mas até quando se inverte o foco desse interesse, em meados do século XIX, e que menos do que escravos, se querem títulos sobre terras, ainda assim se respeita o princípio. Para burlá-lo, inaugura-se um expediente utilizado até hoje: nega-se sua identidade aos índios. E se não há índios, tampouco há direitos. Quanto ao direito constitucional, desde a Constituição de 1934, é respeitada a posse indígena inalienável das suas terras. Diga-se em sua honra, foi na bancada amazonense que teve origem a emenda que consagrou esses direitos em 1934 (Carneiro da Cunha, 1987:84 e ss). Todas as Constituiçóes subseqüentes mantiveram e desenvolveram esses direitos, e a Constituiçáo de 1988 deu-lhes sua expressáo mais detalhada.

Qual é hoje a situaçăo legal dos índios e de suas terras? Sem entrar em muitos detalhes, salientarei alguns dados fundamentais para o que aqui nos interessa. Os índios têm direitos constitucionais, consignados em um capítulo próprio e em artigos esparsos da Constituiçáo Federal 
de 1988. A Constituição trata sobretudo de terras indígenas, de direitos sobre recursos naturais, de foros de litígio e de capacidade processual. Pela Constituição, as terras indígenas são de propriedade da Uniáo e de posse inalienável dos índios. A Constituição não trata da tutela, que é um dispositivo enxertado no Código Civil de 1916. Digo enxertado porque não constava do projeto original de Clóvis Bevilacqua e foi acrescentado para garantir, por analogia com um instituto já existente, proteção especial aos índios. Eles foram assim enquadrados na categoria de relativamente capazes que engloba os menores entre 16 e 21 anos, os pródigos e, até 1962, quando se as retirou do artigo, as mulheres casadas! Trata-se, como se vê pelas outras categorias de relativamente capazes, de defender os índios nas suas transaçóes negociais, tentando impedir que sejam lesados.

$\mathrm{Na}$ legislaçáo ordinária destaca-se o chamado Estatuto do Índio (Lei 6001 de 19.12.73), que regula no detalhe os direitos indígenas. Dadas as novas formulaçóes da Constituiçáo de 1988, faz-se necessária uma revisão desse Estatuto, e tramitam atualmente no Congresso várias propostas de lei nesse sentido.

Há por fim convençóes internacionais ratificadas pelo Brasil que dizem respeito aos índios e das quais a principal seria a Convenção 107 da OIT. Em 1989, a OIT aprovou a revisão da Convenção 107, dando origem à Convenção 169. Está tramitando no Congresso Nacional a proposta de ratificaçăo dessa forma revisada.

Saliento aqui que somente uma Convençáo Internacional ratificada pelo país tem valor legal. Falou-se muito da ameafa que a Declaração dos Direitos dos Povos Indígenas, atualmente em consideração na Subcomissão para a Prevenção da Discriminação e Proteção das Minorias, da Comissão de Direitos Humanos da ONU, faria pesar sobre a soberania brasileira. Sem entrar ainda na análise do conteúdo, quero só fazer notar que uma Declaração não tem qualquer poder de implementação, nem sequer nos foros internacionais.

\section{Substrato das recentes declarações}

Os novos instrumentos internacionais, como a Convençáo 169 da OIT (de 1989), a Declaração dos Direitos dos Povos Indígenas (na sua versão atual) baseiam-se em uma revisão, operada nos anos 70 e sobretudo 80, das noçóes de progresso, desenvolvimento, integraçăo e discriminação ou racismo.

Em poucas palavras, as versões pós-guerra dos instrumentos de direitos humanos baseavam-se essencialmente no direito à igualdade. 
Mas esse direito, que brotava de uma ideologia liberal e respondia a situaçóes do tipo apartheid, foi largamente entendido como um dever; e a igualdade, que era de essência política, foi entendida como homogeneidade cultural. $O$ direito à igualdade redundava pois em um dever de assimilação. Outras equivalências perversas se alastraram: integração e desenvolvimento passaram a sinônimos de assimilação cultural, discriminaçáo e racismo a reconhecimento das diferenças. $O$ anti-racismo liberal, como táo bem analisou Sartre - na sua Reflexcĩo sobre a questão judia -, só é generoso com o indivíduo, nunca com o grupo. Aceita-o desde que se dispa de sua particularidade étnica. Por supor uma igualdade básica, exige um assimilaçáo geral. Naao é diferente nesse sentido a Bula Veritas Ipsa de Paulo III que, em 1537, reconhecia a humanidade dos índios: eram humanos, portanto, passíveis de serem tornados iguais. Tinham alma, portanto, era obrigação dos reis cristáos batizá-los. Essa pseudo-generosidade que quer conceder a todos a possibilidade (inteiramente teórica) de se tornarem semelhantes a nós, deriva de um etnocentrismo que se ignora a si mesmo.

Nos anos 70 e 80 desencadeia-se uma crise de confiança nas idéiaschave de progresso e desenvolvimento, na qual o movimento ecológico teve relevante papel. Sob o impacto dessa crise, o enfoque muda: as declaraçóes internacionais passam a falar em etnodesenvolvimento (Declaraçáo de San José, da UNESCO, de 1981), direito à diferença, valor da diversidade cultural... Direito à diferença, entenda-se, acoplado a uma igualdade de direitos e de dignidade.

Seja como for, as declaraçóes e instrumentos internacionais falam crescentemente, desde o fim dos anos 70 , de popos indigenas. $O$ receio de alguns Estados, e do Brasil em primeira linha, é de que o termo povos possa implicar o status de sujeito de Direito Internacional e, de acordo com a Carta das Naçóes Unidas (art. 1.2) que reconhece o princípio da autodeterminaçáo dos povos, pôr em risco a integridade do território. No entanto, tanto povos como autodeterminafão podem ter entendimentos variados. O fato é que o termo popos se generalizou sem implicar em ameaças separatistas, muito menos no Brasil, em que o tamanho diminuto das etnias e sua pulverizaçáo territorial não permitiriam sequer pensá-lo. Para dissipar mal-entendidos, a Convençăo 169 da OIT e o Acordo Constitutivo do Fundo para o Desenvolvimento dos Povos Indígenas na América Latina e Caribe, criado em 1991, rechaçam explicitamente as implicaçóes temidas pelo Brasil. No seu art. 1, parágrafo 3, a Convenção 169 diz: "A utilizaçăo do termo povos nesta Convençăo não deverá ser interpretada como tendo qualquer implicação com respeito aos direitos que se possa conferir a esse termo no direito interna- 
cional". A vulgarizaçáo do termo povos nos textos internacionais está indo pari passu com a exclusáo explícita de direitos à soberania. Por sua parte, autodeterminafä́o está sendo interpretada nos mesmos textos como vigência do direito costumeiro interno e participaçáo política dos povos indígenas nas decisōes que os afetam, não como reivindicaçáo de soberania. É portanto suspeito, para dizer o mínimo, o grande alarde que se fez na imprensa sobre a ameaça que a Declaraçáo da ONU (que ainda está em rascunho) faria pesar sobre a Amazônia.

Outra variante desse mesmo alarde foi o alegado perigo que a existência de áreas indígenas em faixa de fronteira poderiam representar para a segurança nacional. Curiosamente, esse espectro foi brandido a propósito dos Yanomami e não de outras etnias que também têm populaçáo de um lado e de outro das fronteiras. O Senador Jarbas Passarinho, na época Ministro da Justiça, que assinou a Portaria reconhecendo a área Yanomami, tem sido duramente criticado por setores das Forças Armadas. Ele deu a essas críticas, na Repista do Clube Militar (dirigida por ele em 1954 e 55), uma resposta contundente, em que fala o óbvio: "Qual o risco para a soberania nacional? Nenhum. Pode haver, se assim julgar o Governo, e sem nenhuma necessidade de ouvir o Congresso, a instalaçáo de tantos pelotóes ou companhias de fuzileiros quantas quisermos." E continua lembrando que as terras indígenas sendo propriedade da Uniáo, se houver "superposiçáo com a faixa de fronteira, a Uniāo é duplamente proprietária. Ela exerce sua soberania tanto para com os índios quanto para garantir nossa fronteira, assegurando plenamente a integridade do território brasileiro". A Revista do Clube Militar, em nota final ao artigo do Senador Passarinho, declara no entanto que mantém suas críticas.

Especialistas, como o coronel Cavagnari, coordenador do Núcleo de Estudos Estratégicos da Unicamp, sublinharam em entrevistas recentes (Folba de S. Paulo, 12 ago. 1993) a funcionalidade de inimigos, seja externos como a ONU ou os EUA, seja internos, como os índios, para a existência e recursos das Forças Armadas, carentes de uma missáo desde o fim da Guerra Fria: não há dúvida de que conseguiram, graças a esses inimigos, recursos inesperados e com dispensa de licitaçăo.

Pessoalmente, náo gosto de versōes conspiratórias, mas fez-me refletir uma notícia recente que veio à tona no New York Times: testes feitos em 1984 do programa Guerra nas Estrelas nos EUA e cujo êxito teve na época grande repercussão, teriam sido forjados tanto para se obterem mais verbas para o programa do Congresso Americano quanto para impressionarem a União Soviética, levando-a a se arruinar um pouco mais rapidamente na corrida armamentista. Práticas desta ordem, 
em que o Pentágono e a CIA estariam envolvidos, náo seriam, segundo a revista Time (30 ago. 1993, p.28-29), grandes novidades.

Acho que as Forças Armadas, ou pelo menos alguns de seus setores, têm o grande mérito de planejar a longo prazo. É disto que eu gostaria de falar agora, deixando fantasmas de lado. Ou seja, gostaria de discutir alternativas a longo prazo para nosso convívio com as sociedades indígenas.

\section{Alternativas}

O grande pomo de discórdia, afastados todos os falsos pretextos, alguns dos quais já evoquei, é o tema da exploração dos recursos minerais e dos recursos hídricos em áreas indígenas. Dadas as atuais condiçōes econômicas, o aproveitamento dos recursos hídricos encontra-se atualmente num limbo, mas a questáo mineral está mais viva do que nunca e provavelmente na origem das investidas contra os direitos dos índios.

A Constituição atual prescreve procedimentos especiais quando se trata da exploraçáo de recursos hídricos e minerais em terras indígenas. Não há proibiçăo de explorá-los, mas salvaguardas especiais. Essas salvaguardas consistem na necessidade de autorização prévia do Congresso Nacional, ouvidas as comunidades afetadas que teráo participação no resultado da lavra. Atualmente, a situação está congelada, por ser necessária uma lei ordinária regulamentando a matéria. Várias propostas de lei estáo tramitando e em recentíssimas reuniōes com várias entidades, o Ministério de Minas e Energia tentou apressar as negociaçóes para a regulamentaçáo rápida da questáo.

O que está em causa, na realidade, é o modelo que o país deseja para si mesmo e o papel das populaçóes indígenas nesse modelo. Temos hoje, no Brasil, a possibilidade de estabelecer um planejamento estratégico que beneficia o país e abre espaço para um papel importante das populaçóes tradicionais da Amazônia, populaçóes que até agora sempre foram relegadas a um plano secundário, quando não, vistas como obstáculos.

A riqueza da Amazônia não compreende apenas seus minérios, suas madeiras, seus recursos hídricos, mas também sua biodiversidade e os conhecimentos de que se dispóem acerca delas. Um exemplo: há pelo menos umas 250.000 espécies vegetais, das quais cerca de 150 sáo usadas como alimento; $95 \%$ da alimentação mundial repousa sobre apenas 30 espécies o que torna a humanidade particularmente vulnerável, já que o aparecimento de novos vírus pode afetá-las e provocar a fome mun- 
dial. Daí decorre a importância estratégica fundamental de bancos genéticos e de sementes que permitem novos pontos de partida. Nos anos 70, uma espécie selvagem de milho foi descoberta no México. Trata-se da única espécie perene de milho e é resistente a doenças. Essa preciosidade foi descoberta in extremis : subsistiam apenas dez hectares de terra no mundo em que ela podia ainda ser encontrada. Mas que foi feito das 30.000 variedades de arroz que os agricultores indianos cultivavam originalmente?

As variedades vegetais evoluem e eventualmente co-evoluem com microorganismos. A conservaçâo no seu local de origem é táo essencial quanto a conservação nos bancos de germoplasma. Essa conservação não é obra simplesmente da natureza: geraçōes de cultivadores foram cruciais para descobrir o valor das espécies, selecioná-las e mantê-las até nossos dias. Por isso a FAO, órgáo da ONU, reconheceu os direitos dos agricultores (leia-se: populaçóes tradicionais) em virtude de sua contribuição à conservação, melhoria e disponibilidade dos recursos fitogenéticos e estabeleceu um Fundo Internacional para os recursos fitogenéticos que deveriam remunerar essa contribuiçăo.

Estima-se em cerca de um milhão e meio o número de espécies vivas no planeta. Por onde começar a explorar essa riqueza que continuamente diminui antes que possamos realmente avaliá-la? Como descobrir em prioridade as virtudes medicinais de certas espécies? O conhecimento acumulado por geraçóes de populaçōes tradicionais tem sido o guia mais usado nas pesquisas.

Tudo isto aponta para dois aspectos: primeiro, que a riqueza biológica é uma das mais estratégicas para o século XXI. O germoplasma, segundo o Instituto de Recursos Mundiais em Washington, pode ser o petróleo da Era da Informaçăo (Elkington, 1986 apud Kloppenburg \& Vega, 1993). Segundo, que o conhecimento das populaçóes tradicionais, e especialmente das populaçóes indígenas, é fundamental para sua exploraçấo.

O Brasil, como vários países do hemisfério sul, é biologicamente rico. Mas, mais do que a maioria dos países, é rico também em populaçōes que conservam e desenvolvem conhecimentos sobre as espécies vivas. $O$ que parecia pobreza, o pequeno número de indivíduos em cada sociedade indígena, a ênfase na diversidade de produtos e na exploraçáo ampla dos recursos em vez de uma agricultura centrada em poucas espécies, revela-se agora um trunfo.

Até agora, esta informaçáo genética e o conhecimento acumulado sobre a natureza năo entraram realmente no mercado. Mas o mundo (e 
os bancos multilaterais já o têm demonstrado) está disposto a contribuir para algo que é essencial para todos. É preciso estabelecer ou reforçar os mecanismos para tanto.

Resumindo: em uma perspectiva estratégica, é irracional querer abrir todas as áreas da Amazônia à exploração indiscriminada.

As populaçóes indígenas têm direito a seus territórios por motivos históricos, que foram reconhecidos no Brasil ao longo dos séculos. Mas estes direitos não devem ser pensados como um óbice para o resto do país: ao contrário, são pré-requisito da preservação de uma riqueza ainda inestimada mas crucial. O que se deve procurar, no interesse de todos, é dar as condiçóes para que esta riqueza não se perca. Fazem-se assim coincidir os direitos dos índios com os interesses da sociedade brasileira. Foi nessa mesma perspectiva que a Coordenação Nacional dos Geólogos defendeu na Constituinte (e contra as mineradoras) que as áreas indígenas se tornassem reservas nacionais de recursos minerais, ou seja, as últimas a serem exploradas.

Para a conservação da riqueza biológica, o raciocínio deveria ser semelhante: em 1990, as áreas ambientais protegidas na Amazônia (federais e estaduais) somavam aproximadamente 17 milhóes de hectares. Avalia-se que, se a floresta tropical for preservada apenas nos parques e reservas ambientais existentes, $66 \%$ das espécies podem ser extintas. Tanto para evitá-lo quanto para preservar conhecimentos, é preciso estabelecer um novo pacto com as populaçōes indígenas, para que contribuam para a conservaçăo da riqueza brasileira.

Por que é necessário um pacto? Porque, contrariamente à visão ingênua que muitos têm dos índios, não se pode esperar que naturalmente eles se encarreguem desse serviço à coletividade. As sociedades indígenas, vivendo em suas formas tradicionais e em territórios suficientemente amplos, têm preservado e enriquecido seu meio ambiente, já que dependem dele. Muitos têm até mantido, em áreas de devastaçáo como no corredor da Grande Carajás, ilhas de preservação relativa. Mas a pressáo externa é grande sobre seus recursos naturais, sejam eles madeira ou recursos minerais, e essa pressão toma a forma de cooptação ou divisão de lideranças. Toma às vezes formas ainda mais graves: há dois meses, no dia 14 de agosto, o chefe nambiquara Pedro Mamaindé, que impedia a venda de madeira da Área Indígena Vale do Guaporé, foi assassinado por outro índio, Sebastiáo Pareci, o qual, pelo que se sabe, tinha ligaçóes com madeireiras da cidade de Comodoro, no estado do Mato Grosso. É por isso que propostas de regulamentação da mineração, como as que apresenta o Ministério de Minas e Energia, são peri- 
gosas. No lugar de verificar a essencialidade para o país de se minerar em determinada área, propóe-se a simples consulta à comunidade, à qual se oferece, por outra parte, substancial remuneração. É fácil prever-se o desfecho de tais ofertas, em comunidades privadas de alternativas.

A floresta amazônica e a biodiversidade interessam ao mundo e o mundo está disposto a pagar por elas. Já há mecanismos como, por exemplo, o Fundo Global de Meio Ambiente, gerido pelo Banco Mundial, que compensa regiốes ou países por renunciarem ao aproveitamento imediato de uma riqueza em favor da conservaçáo ambiental. Assim, se Roraima aceitar o desintrusamento de suas áreas indígenas poderá se beneficiar, entre outras coisas, da pavimentação da estrada que liga Manaus à Venezuela ou da construção de pequena hidrelétrica. $O$ que é verdade para o Brasil e para Roraima deve também ser verdade para as sociedades indígenas: ou seja, a elas também se deve compensar, oferecendo alternativas sustentáveis para a obtenção de recursos.

Muitas lideranças indígenas já demonstraram seu interesse referente ao pacto de que estou falando: é o caso em particular do Yanomami Davi Kopenaua, era o caso do chefe Mamaindé assassinado em agosto. Nem mais índios nem menos índios do que os Kaiapó que, renunciando a combater o garimpo que os invadia de todos os lados, resolveram tolerá-lo e taxá-lo.

Volta à surrada idéia do bom selpagem ecológico? Sim e não. Sim, como possibilidade de um papel importante para os índios no nosso futuro comum; não, porque esse papel não repousa sobre alguma essência que thes seja atribuída. A posiçăo dos índios no Brasil de hoje e de amanhã desenhar-se-á na confluência de várias opçóes estratégicas, tanto do Estado brasileiro e da comunidade internacional quanto das diferentes etnias. Trata-se de parceria.

\section{Sócio-diversidade}

Deixei por último uma questáo crucial, a da chamada sócio-diversidade. As culturas constituem para a humanidade um patrimônio de diversidade, no sentido de apresentarem soluçóes de organizaçáo do pensamento e de exploração de um meio que é, ao mesmo tempo, social e natural. Como fez notar Lévi-Strauss em uma conferência feita no Japão há alguns anos, nesse sentido a sócio-diversidade é tão preciosa quanto a bio-diversidade. Creio, com efeito, que ela constitui essa reserva de achados na qual as futuras geraçóes poderáo encontrar exemplos - e quem sabe novos pontos de partida - de processos e sínteses sociais já postos à prova. Este ponto de vista, por mais natural que nos 
possa parecer hoje, náo é auto-evidente. Supóe ter caducado o modelo ingenuamente evolucionista que dominou nossa civilização durante mais de um século e que impregnou o senso comum. $O$ progresso erigiu uma história particular, a nossa, em ponto de chegada da humanidade. Tivemos recentemente na USP uma conferência de Stephen Jay Gould, na qual enfatizou que o sucesso da cadeia evolutiva que culminou nos vertebrados e no homem dependeu apenas de uma loteria, não de uma necessidade. Nada havia de melhor, de mais adaptativo na cadeia que prosperou do que em várias outras cadeias que abortaram. Foi acaso e não necessidade. Com isso, perderam-se formas vivas, algumas muito promissoras. Se quisermos continuar a usar a evoluçăo como paradigma, teremos de avaliar também as nossas perdas sociais: processos desaparecidos e línguas mortas são, como as variedades botânicas extintas ou as cadeias evolutivas que abortaram, possibilidades aniquiladas.

Não se pense que há contradição entre esta perspectiva e a de que as culturas são entidades vivas, em fluxo. Quando se fala do valor da sócio-diversidade, não se está falando de traços e sim de processos. Para mantê-los em andamento, o que se tem de garantir é a sobrevivência das sociedades que os produzem. No início desta conferência mencionei que os sistemas multiétnicos sobredeterminam os sistemas sociais: à lógica interna que os anima acrescentam uma lógica externa que os coloca em relaçáo com outros sistemas. Mas, do mesmo modo que o totemismo não dissolve as espécies vivas, tampouco o sistema multiétnico dissolve as sociedades tradicionais. No nosso mundo atual, ele é, pelo contrário, sua condição de sobrevivência.

\section{Referências bibliográficas}

BRAUDEL, Fernand. Civilisation mattrielle, Cconomic et capitalisme XVe-XVWII sidcle. Tome I. Paris, Armand Colin, 1979, 544p.

CARNEIRO DA CUNHA, Manuela. Os direitos dos trdios. Sáo Paulo, Brasiliense, 1987.

CEDI. Terras indigenas no Brasil. Situagato das pendencias jurtdico-adoninistrativas das terras indigenas para o cumprimento do art. 67 das disposifóes transiturias da Constituiguto Federal. 10 set. 1993 , ms.

DENEVAN, William. The aboriginal population of Amazonia. In: W. Denevan (ed.) The native population of the Americas. The University of Wisconsin Press, p.205-235.

ELKINGTON, John. Double dividends? U.S. Biotechmology and Third World Development. WRI Paper n= 2, Washington DC, World Resources Institute, 1986.

KLOPPENBURG JR, Jack \& VEGA, Tirso A. Gonzáles. Probibido cazar! Expoliación cien- 
tificn, Los dereclsos indigenas y la biodiversidad universal. Comunicaçáo ao Encuentro Internacional. Biotecnologia, Recursos Genéticos y el Futuro de la Agricultura en los Andes. Piura, Peru, Comisión Coordinadora de Tecnología Andina, CCTA, 1992 (no prelo).

\title{
Resumo
}

O futuro dos índios no Brasil dependerá de várias opçōes estratégicas, tanto do Estado brasileiro e da comunidade internacional quanto das diferentes etnias. Trata-se de parceria. As populaçōes indígenas têm direito a seus territórios por motivos históricos, que foram reconhecidos no Brasil ao longo dos séculos. Mas estes direitos não devem ser pensados como um óbice para o resto do Brasil: ao contrário, são um pré-requisito da preservação de uma riqueza ainda inestimada mas crucial, a biodiversidade e os conhecimentos das populaçóes tradicionais sobre as espécies naturais. O que se deve procurar, no interesse de todos, é dar as condiçōes para que esta riqueza não se perca: é por isso irracional querer abrir todas as áreas da Amazônia à exploração indiscriminada. Fazem-se assim convergir os direitos dos índios com os interesses da sociedade brasileira como um todo.

\begin{abstract}
The indians future in Brazil will depend on several strategic choices as much the Brazilian state and international community as different races. It is a question of partnership. By historical reasons, which were recognized in Brazil during the centuries, the native populations have a right to their territories. But these rights should not be thought as an impediment to the rest of the country. On the contrary, they are a preserving prerequisite of a richness even inestimable, but cruciate, the biodiversity and knowledges of traditional populations about natural kinds. According to everybody's interest what it should look for is to give conditions not to loose this richness. Because of that, it is unreasonable want to open all Amazonia areas to indiscriminate exploration. Thus, it is necessary converge the indians rights with the brazilian society interests as a whole.
\end{abstract}

Manuela Carneiro da Cunba é professora titular do Departamento de Antropologia da Faculdade de Filosofia, Letras e Ciências Humanas da Universidade de Săo Paulo. É autora, entre outros, do livro Antropologia do Brasil - Mito, Historia e Etnicidade (São Paulo, Brasiliense-Edusp, 1986), e organizadora de Legislaçăo Indigenista no Brasil (Função Pró-Índio de São Paulo-Edusp, 1992).

Conferência do Mês do IEA-USP feita pela autora em 28 de setembro de 1993. 